\title{
POPULATION DYNAMICS OF BOMBAY DUCK HARPODON NEHEREUS (HAMILTON, 1822) OF THE BAY OF BENGAL ALONG BANGLADESH COAST
}

\author{
M.N. Sarker*, Md. Humayun¹, Md. Atiar Rahman and Md. Sharif Uddin
}

Bangladesh Marine Fisheries Capacity Building Project, Department of Fisheries, Matshya Bhaban, 13, Shahid Captain Monsur Ali Sarani, Ramna, Dhaka-1000, Bangladesh

\begin{abstract}
Population parameters of Harpadon nehereus were estimated using FiSAT-II. length-frequency data collected from different landing centers along the coast of Bangladesh. The Von Bertalanffy growth parameters $\mathrm{L}_{\infty}$ and $\mathrm{K}$ for the species were $45.05 \mathrm{~cm}$ and 1.30/year, respectively. The annual rate of natural mortality (M) and fishing mortality (F) were found to be 1.86 and 2.58, respectively. The estimated value of the exploitation rate (E) using the lengthconverted catch curve was 0.58 and $\mathrm{E} \max$ was found to be 0.582 . The recruitment pattern of this species was continuous and two peaks per year. The present investigation clearly showed the over fishing $(E>0.50)$ condition for $H$. nehereus in Bangladesh. The estimated length-weight relationship for the combined sex was found to be $\mathrm{W}=0.003199 \mathrm{~L}^{3}$.

Key words: Asymptotic length, growth coefficient, mortality, virtual population analysis, recruitment pattern, exploitation rate, Harpadon nehereus.
\end{abstract}

\section{INTRODUCTION}

Harpadon nehereus (Hamilton 1822) is one of the highly esteemed table fish at home and abroad, but little work has so far been done on it in the field of population dynamics. It is popularly known as Bombay duck. It is distributed in the inshore shallow water and estuarine fish of the Bay of Bengal, Indian Ocean and the Arabian sea. This fish is locally familiar as 'Lotiya Machh' or 'Loitta' around the coastal areas of Bangladesh. Growth and mortality aspects of Bombay duck of Bay of Bengal have been studied by many authors. Mustafa et al. (1998), Khan (1989) reported that for $H$. nehereus $\mathrm{K}=0.76 /$ year, $\mathrm{L}_{\infty}=425$ $\mathrm{mm}$ along the Saurashtra coast, India. Kurian and Kurup (1992) reported $\mathrm{K}=0.52 /$ year, $\mathrm{L}_{\infty}=426 \mathrm{~mm}$ along the Maharastra coast, India. Mustafa (2003) reported $\mathrm{L}_{\infty}=24.48 \mathrm{~cm} \mathrm{~K}=1.50$ per year in the Bay of Bengal.

The present study was undertaken to estimate the key parameters of stock assessment and its population dynamics like asymptotic length $\left(\mathrm{L}_{\infty}\right)$, growth coefficient $(\mathrm{K})$, total mortality $(\mathrm{Z})$, natural mortality $(\mathrm{M})$, fishing mortality $(\mathrm{F})$, exploitation rate $(E)$, recruitment pattern, relative yield/recruit $\left(Y^{\prime} / R\right)$, relative biomass/recruit ( $\left.\mathrm{B}^{\prime} / \mathrm{R}\right)$ and virtual population analysis (VPA) etc. for $H$. nehereus.

*Author for correspondence: <mn_sarker2001@yahoo.com>. ${ }^{1}$ Center for Development Initiatives in Capture Fisheries (CDICF), 27/A, Siddeshwari Lane, Ramna, Dhaka-1217, Bangladesh.

두 2017 Zoological Society of Bangladesh DOI: http://dx.doi.org/10.3329/bjz.v45i2.35705 


\section{MATERIAL AND METHODS}

Length-frequency data of Harpadon nehereus were collected weekly from the commercial catches from 35 different landing centers of Bangladesh coastal districts from September, 2013 to August, 2014. Samples of H. nehereus were mainly caught by set bag net, seine net and gill nets. Random samples of 6,411 specimens were collected. The length-frequency data were pooled month-wise.

Study area: The study area was from Cox's Bazar to Satkhira. Data collected from 35 selected marine fish landing stations under 49 upazilla of 14 districts along the coastal belt of the Bay of Bengal.

Data processing and analysis: Estimation of Asymptotic length $\left(\mathrm{L}_{\infty}\right)$ and Growth co-efficient (K): Month-wise length-frequency data were used to estimate the total asymptotic length $\left(\mathrm{L}_{\infty} \mathrm{cm}\right)$ and growth co-efficient (K/year) of the Von Bertalanffy growth equation (Bertalanffy 1938, Beverton and Holt, 1957). The data collection period started from September and continued up to August 2013. The ELEFAN I and ELEFAN II routines incorporated in FiSAT II (FAO ICLARM Stock Assessment Tools) Software (Gayanilo et al. 2005) were used to determine $\mathrm{L}_{\infty}$ and $\mathrm{K}$ values following the Powell-Wetherall method (Wetherall et al. 1987). This method was used to provide an initial estimate of $\mathrm{L}_{\infty}$. This initial estimate of $\mathrm{L}_{\infty}$ was then used as seed value to determine the value of $\mathrm{K}$ (Silvestre and Graces 2004). Minor adjustments to $\mathrm{L}_{\infty}$ and $\mathrm{K}$ were made to maximize the 'goodness of fit' criterion built in to ELEFAN I (Pauly 1987). This led to a preliminary estimate of $\mathrm{L}_{\infty}$ and $\mathrm{K}$ that were used to obtain "probability of capture" by length class using the routine in FiSAT. These "probability of capture" were used to correct the length-frequency distribution data to account for incomplete selection and recruitment and the final estimate of $\mathrm{L}_{\infty}$ and $\mathrm{K}$ were obtained by using the corrected length-frequency data through ELEFAN I (Silvestre and Graces, 2004). ELEFAN I was used to estimate the growth parameters based on the Von Bertalanffy Growth Formula (VBGF) expressed in the form (Pauly and Gaschutz 1979):

$$
\mathrm{L}_{\mathrm{t}}=\mathrm{L}_{\infty}\left\{1-\exp \left[-\mathrm{K}\left(\mathrm{t}-\mathrm{t}_{\mathrm{o}}\right)\right]\right\}
$$

where, $L_{t}$ is the predicted length at time $t, L_{\infty}$ is the asymptotic length or maximum length of a given stock of a fish, $\mathrm{K}$ is the growth constant, also called 'stress factor' by Pauly 1980 and to is the "age" the fish would have been at zero length.

Growth performance: The growth performance of $H$. nehereus population in terms of length was compared using the index of Pauly and Munro (1984),

$\phi^{\prime}=\log _{10} \mathrm{~K}+2 \log _{10} \mathrm{~L}_{\infty}$ 
[Phi prime $\phi^{\prime}$ is much used as the probably best means of averaging growth parameters of a particular species. $\phi^{\prime}$ is calculated for each datum set and averaged. Inserting a value $\mathrm{L}_{\infty}$ for instances the mean of all estimates gives a value of $\mathrm{K}$ corresponding to the $\mathrm{L}_{\infty}$ inserted, whenever $\mathrm{L}_{\infty}$ and $\mathrm{K}$ are estimated from a new set of datum for the same species calculation of $\phi^{\prime}$ indicates if the new pair of $L_{\infty}$ and $K$ is in accordance with previous result. The new $\phi^{\prime}$ should be close to the previous estimate, because $\phi^{\prime}$ is the constant in the regression of $\log \mathrm{K}+2 \log \mathrm{L}_{\infty}$. (Sparre and Venema 1998).

Mortality estimation: In FiSAT II software package (Gayanilo et al, 2005, ELEFAN II was used to estimate the total mortality $Z$ (per year) using the length converted catch curve by means of final estimates $\mathrm{L} \infty$ and $\mathrm{K}$ and lengthfrequency data (Beverton and Holt 1957, 1966) for the species H. nehereus. The rate of natural mortality $\mathrm{M}$ (per year) for the species was calculated by using Pauly's empirical equation (Pauly 1983):

$$
\operatorname{Ln} M=-0.0152-0.279 \operatorname{Ln}\left[\mathrm{L}_{\infty}\right]+0.6543 \operatorname{Ln}[\mathrm{K}]+0.463 \mathrm{Ln}[\mathrm{T}]
$$

This formula was used to obtain the estimate of $M$, given $\mathrm{L}_{\infty}$ in $\mathrm{cm}, \mathrm{K}$ the growth constant and $\mathrm{T}$ the mean environmental temperature ${ }^{\circ} \mathrm{C}$. Once $\mathrm{Z}$ and $\mathrm{M}$ were obtained, then fishing mortality $\mathrm{F}$ was derived from the relationship $\mathrm{F}=\mathrm{Z}-$ $M$ (Silvestre and Graces 2004). The exploitation rate $E$ was obtained by the relationship: $\mathrm{E}=\mathrm{F} / \mathrm{Z}=\mathrm{F} /(\mathrm{F}+\mathrm{M})$ (Beverton and Holt 1956, Ricker 1975).

Probability of capture: Probability of capture calculated from the length converted catch curve routine and estimated the final $\mathrm{L}_{25}, \mathrm{~L}_{50}$ and $\mathrm{L}_{75}$ (Length at which 25, 50 and 75\% of fish would be vulnerable to the gear (Pauly 1984).

Recruitment pattern: Recruitment Pattern was obtained by the backward projection of the frequencies on the time axis of a time series of samples along a trajectory defined by the Von Bertalanffy growth equation (Moreau and Cuende 1991). This routine reconstructs the recruitment pulses from time series of length-frequency data to determine the number of pulses per year and the relative strength of each pulse (Gayanilo et al. 2005).

Virtual population analysis (VPA): The terminal population $\left(\mathrm{N}_{\mathrm{T}}\right)$ was estimated from $\mathrm{Nt}=\mathrm{Ct}(\mathrm{M}+\mathrm{Ft}) / \mathrm{Ft}$. Where $\mathrm{Ct}$ is the terminal catch, and $\mathrm{Ft}$ is the terminal fishing mortality and $\mathrm{M}$ is the natural mortality. Starting from $\mathrm{N}_{0}$ successive value of $\mathrm{F}$ was estimated by iteratively solving:

$\mathrm{Ci}=\mathrm{Ni}+\Delta \mathrm{t}(\mathrm{Fi} / \mathrm{Zi})(\exp (\mathrm{Zi} \Delta \mathrm{ti})-1 \quad$ (Gayanilo et al. 2005).

Where $\mathrm{Ci}=$ Catch (in number) for a population during a unit time period $\mathrm{i}$,

$\Delta \mathrm{ti}=\left(\mathrm{t}_{\mathrm{i}+1}-\mathrm{ti}\right)$ and $\mathrm{ti}=\left[\mathrm{t}_{0}-(1 / \mathrm{K}) \mathrm{Ln}\left(1-\mathrm{Lt} / \mathrm{L}_{\infty}\right)\right]$.

The population size $\mathrm{Ni}$ was computed from $\mathrm{Ni}=\mathrm{N}_{\mathrm{i}}+\Delta \mathrm{ti}$ exp (Zi). The last two equations were used alternatively until the population sizes and fishing 
mortality for all length groups have been computed (Jones and van Zalinge, 1981, Moreau and Cuende 1991).

Relative yield-per-recruit and relative biomass-per-recruit: The Relative Yieldper-Recruit $\left(\mathrm{Y}^{\prime} / \mathrm{R}\right)$ was computed using the following formula (Gayanilo and Pauly 1997, Beverton and Holt 1966):

$$
\mathrm{Y}^{\prime} / \mathrm{R}=\mathrm{E} \cdot \mathrm{U} \mathrm{M} / \mathrm{K}\left\{1-\frac{3 U}{(1+m)}+\frac{3 U^{3}}{(1+2 m)}-\frac{U^{3}}{(1+3 m]}\right\}
$$

Where, $\mathrm{U}=1-\left(\mathrm{Lc} / \mathrm{L}_{\infty}\right), \mathrm{m}=(1-\mathrm{E}) /(\mathrm{M} / \mathrm{K})=\mathrm{K} / \mathrm{Z}, \mathrm{Lc}=$ length of fish at first capture i.e. length at which $50 \%$ of the fish are retained by the gear and $\mathrm{E}=$ $\mathrm{F} / \mathrm{Z}$.

Relative biomass/recruit $\mathrm{B}^{\prime} / \mathrm{R}$ was estimated from the relationship $\mathrm{B}^{\prime} / \mathrm{R}=$ $\left(\mathrm{Y}^{\prime} / \mathrm{R}\right) / \mathrm{F}$

The values of Emax, EO.1 and EO.5 were estimated by using the first derivative of this function, where, Emax = Maximum sustainable exploitation rate, EO.1= Exploitation rate at which the marginal increase of relative yield/recruit is $1 / 10$ th and E0.5 = Value of E under which the stock has been reduced to $50 \%$ of its unexploited biomass.

\section{RESULTS AND DISCUSSION}

Growth parameters: Growth parameters of the VBGF were estimated as $\mathrm{L}_{\infty}=$ $45.05 \mathrm{~cm}$ and $\mathrm{K}=1.30$ /year. For these estimates "K Scan" option of the FiSAT II was used as recommended by Gayanilo et al. (2005). The computed growth curve produced with those parameters is shown over its restructured length distribution in Fig. 1. The to value was taken as 0. Mustafa et al (1998) reported $\mathrm{L}_{\infty}=24.48 \mathrm{~cm}$ and $\mathrm{K}=1.50 /$ year and Mustafa et al. (1994) reported $\mathrm{L}_{\infty}=29.00$ $\mathrm{cm}$ and $\mathrm{K}=0.9$ /year for $H$. nehereus from the Kumira estuary and Islam (1995) also reported that $\mathrm{L}_{\infty}=30.00 \mathrm{~cm}$ of the species in the Karnafully estuary of

Bangladesh. Khan (1989) reported that for $H$. nehereus $\mathrm{K}=0.7618, \mathrm{~L}_{\infty}=425$ $\mathrm{mm}$ along the Saurashtra coast, India. Kurian and Kurup (1992) reported that $\mathrm{K}=0.52 /$ year, $\mathrm{L}_{\infty}=426 \mathrm{~mm}$ along the Maharashtra coast, India. Calculated growth performance index $\phi^{\prime}$ was found to be 3.42 .

Mortality: The mortality rates $\mathrm{M}, \mathrm{F}$ and $Z$ computed are 1.86, 2.58 and 4.44, respectively. Fig. 2 represents the catch curve utilized in the estimation of $Z$. The dark circles represent the points used in calculating $Z$ through least square linear regression. The blank circles represent points either not fully recruited or nearing to $\mathrm{L}_{\infty}$ hence discarded from calculation. Good fit to the descending right hand limits of the catch curve was considered. Mustafa et al. (1994) computed $\mathrm{M}, \mathrm{F}$ and $\mathrm{Z}$ were $2.46,3.27$ and 5.73, respectively from Kumira, Chittagong in 
the Bay of Bengal. Balli et al. (2011) estimated M, F and $Z$ were 1.30, 3.03 and 4.33, respectively from Mumbai waters, India. Khan (1989) estimated $Z, M$ and $F$ $2.784,1.572$ and 1.212, respectively along the Saurashtra coast, India.

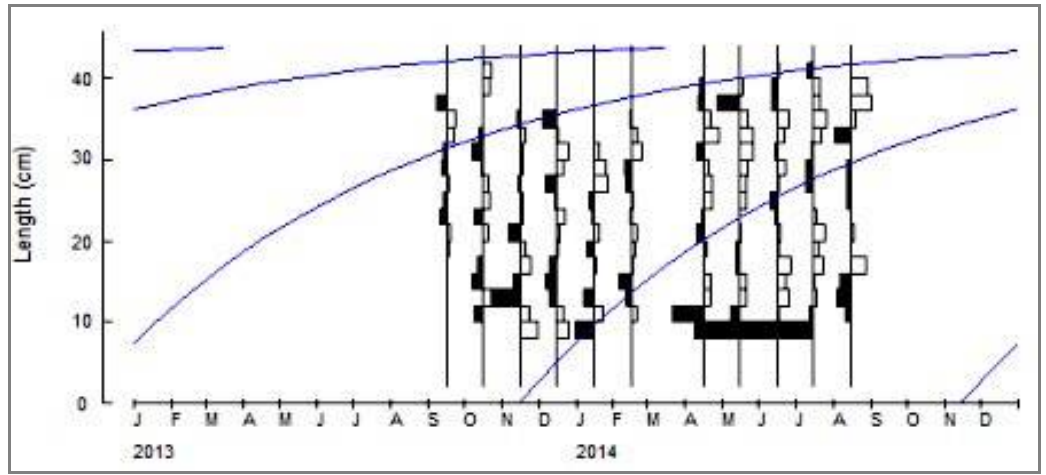

Fig. 1. Growth curve of $H$. nehereus from Bangladesh by ELEFAN I superimposed on the restructured length-frequency $\left(\mathrm{L}_{\infty}=45.05 \mathrm{~cm}\right.$ and $\left.\mathrm{K}=1.30 / \mathrm{yr}\right)$

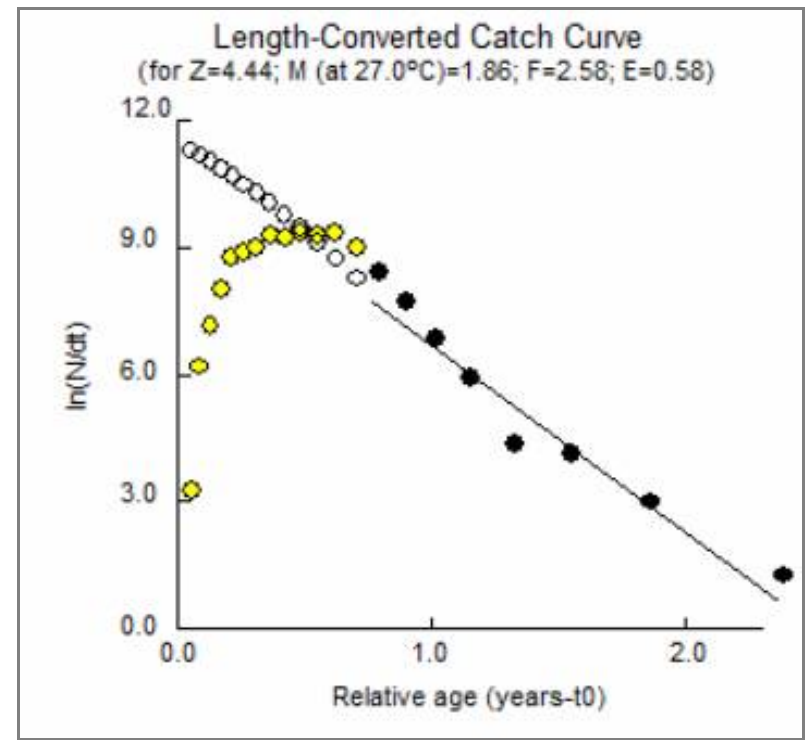

Fig. 2. Length converted catch curve of $H$. nehereus.

Exploitation rate: The exploitation rate $(\mathrm{E})$ has been estimated from the Gulland's (1971) equation, $E=F / F+M$. From these range of values of $F$ and $Z$ it can be shown that the rate of exploitation (E) is 0.58. It appears that the stock of $H$. nehereus of the coastal area of Bangladesh is under fishing pressure. This assumption is based on Gulland (1971) who stated that suitable yield is 
optimized when $\mathrm{F}=\mathrm{M}$ and when $\mathrm{E}$ is more than 0.5, the stock is generally supposed to be over fishing. Mustafa et al. (1994), Islam (1995) and Mustafa et al. (1998) also reported the over exploitation of the species in the coastal region of Bangladesh. Balli et al. (2011) observed the exploitation rate 0.66 in Mumbai waters in India.

Probability of capture: The estimated length sizes for $25 \%\left(\mathrm{~L}_{25}\right), 50 \%\left(\mathrm{~L}_{50}\right)$ and $75 \%\left(\mathrm{~L}_{75}\right)$ probabilities of capture would be $13.76,17.50$ and $19.80 \mathrm{~cm}$, respectively for $H$. nehereus (Fig. 3). Mustafa et al. (1998) found $L_{c}$ i.e., $L_{50}$ as 6.747. But this is likely to differ in case of commercial fish trawlers having different mesh size in the cod end.

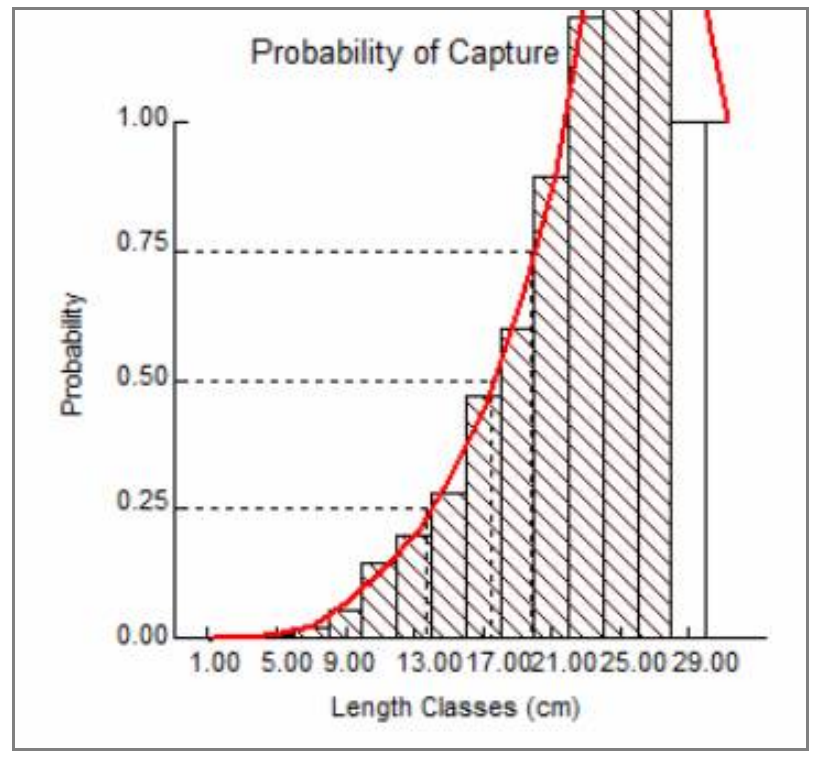

Fig. 3. Probability of capture of $H$. nehereu.

Recruitment pattern: Two recruitment peaks were found for $H$. nehereus one in March-May and another in August-November (Fig 4). Two peaks in recruitment for several fishes were reported by Russell et al. (1977), Williams and Sale (1981) and Mustafa et al. (1998).

Virtual population analysis (VPA): The Length-structured VPA is a powerful tools for fish stock assessment by which the size of each cohort is estimated along with the annual mortality caused by fishing. The $\mathrm{F}$ at length array showed in (Fig. 5) that the maximum fishing mortality occurring in the length between 10 to $32 \mathrm{~cm}$ with a maximum value in the length of $32 \mathrm{~cm}$ that repeatedly indicate high fishing mortality in the $H$. nehereus. Large quantities of juveniles are caught particularly during February-May as a result the $Z$ is high. The 
commercial sized fish in the catch is very poor during February-May. The commercial size (210 and above) is much below the size at first maturity 250 mm (Khan 1989).

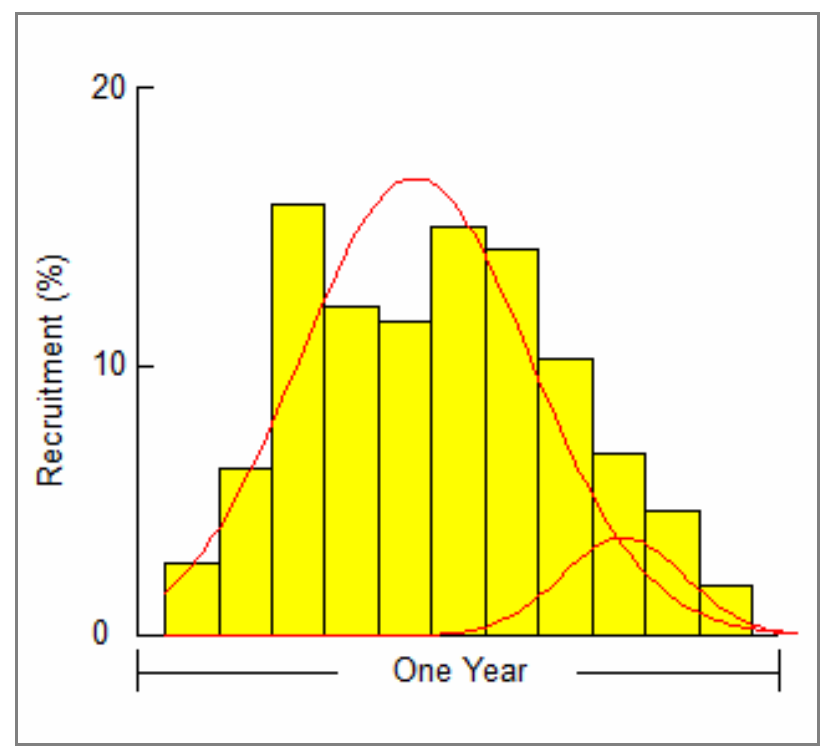

Fig. 4. Recruited pattern of $H$. nehereus on the basis of data of one year starting from September to August.

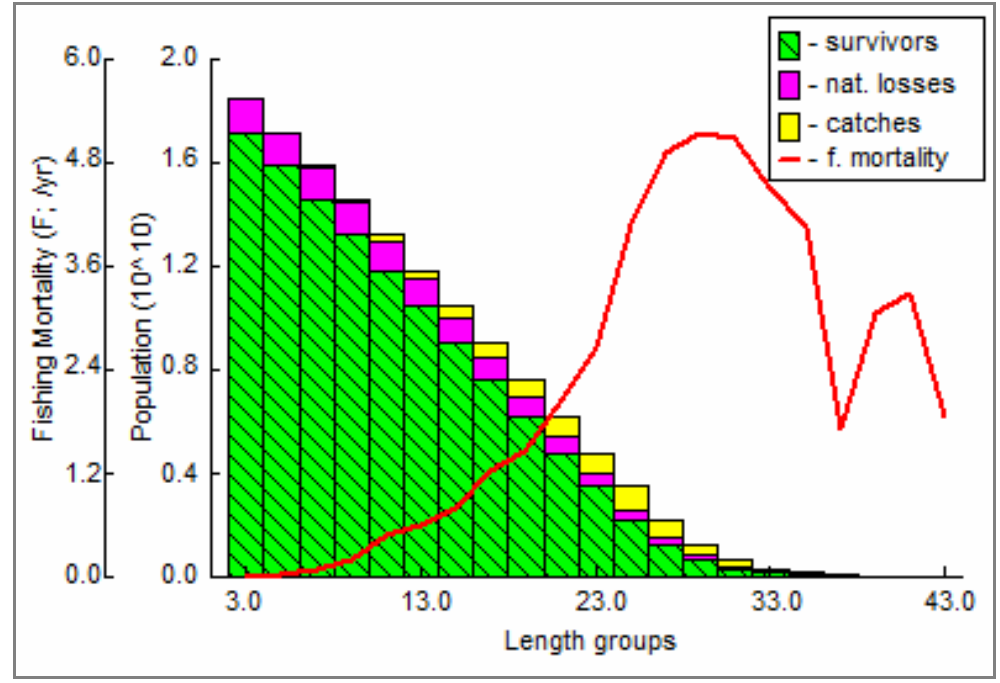

Fig. 5. Length-structured virtual population analysis of $H$. nehereus. 


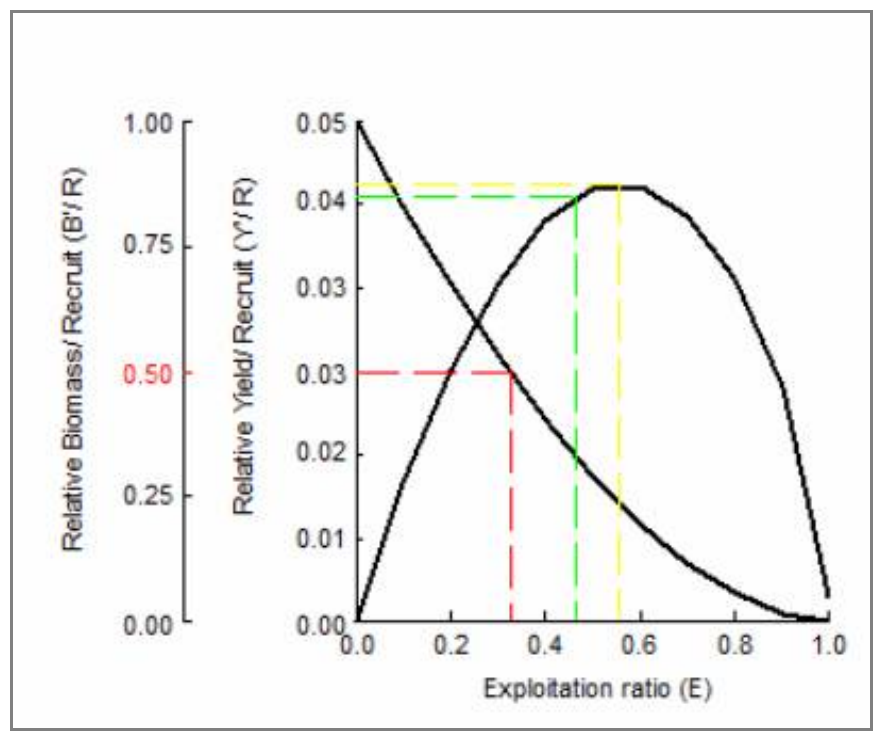

Fig. 6. Relative yield/recruit and biomass/recruit of $H$. nehereus.

Yield/recruit and biomass/recruit: The relative Yield-per-recruit and Biomass-per-recruit were determined as a function of $\mathrm{Lc} / \mathrm{L}_{\infty}$ and $\mathrm{M} / \mathrm{K}$ were 0.388 and 1.430 respectively. The $\mathrm{E}_{0.1}$ and $\mathrm{E}_{0.5}$ were found to be 0.466 and 0.325 respectively (Fig. 6) showed that the present exploitation rate $\mathrm{E}=0.58$ exceeds the optimum exploitation rate $\mathrm{E}=0.50$. The studies on yield per recruits indicate 6 - 9\% higher yield from 25 and $27 \mathrm{~mm}$ cod end dol net, respectively which is already in vogue at Satpati, Maharashtra (Khan 1989). It is evident that whenever the catch has exceeded the estimated MSY there has been a decline in the catch in succeeding year. It may appear, because of self regulatory nature of dol net fishing, that no management policies are needed. But the following observations have to be taken into consideration before coming to any conclusion (Khan 1989).

\section{CONCLUSION}

The Bay of Bengal is being considered with vast biodiversity and it is capable of supporting various fish species including $H$. nehereus. From the findings of the present study it can be concluded that the stock of $H$. nehereus is in overexploitation level. Any major change in the existing fishing level/exploitation will most likely result in a reduction in the yield per recruit and thereby hamper the MSY. Therefore, protection from any over exploitation, prohibition of indiscriminate fishing with non-allowable mesh size gears/nets, banning of fishing particularly during the spawning season of the studied species are 
recommended, which in turn will help to manage this fishery in a more sustainable way. The findings of the present study will help to formulate the management and conservation policies of this species and would be helpful for further development of this species in Bangladesh.

Acknowledgement: The authors are grateful to Bangladesh Marine Fisheries Capacity Building Project, Department of Fisheries for supporting this work.

\section{LITERATURE CITED}

BALli, J.J., CHAKRABORTY, S.K. and JAISWAR, A.K. 2011. Population dynamics of Bombay duck Harpadontidae nehereus (Ham. 1822) (Teleostomi/Harpadontidae) from Mumbai waters. Indian Journal of Geo-Marine Sciences 40(1): 67-70.

BERTALANFFY, L.V. 1983. A quantitative theory of organic growth. Human Biology 10:181-213.

BEVERTON, R.J.H. and HOLT, S.J. 1956. A review of methods for estimating mortality rates in fish populations with special references to sources of bias in catch sampling. Rapp. P-V. Renn. Cons. Int. Explor. Mer. 140: 67-83.

BEVERTON, R.J. and HOLT, S.J. 1957. On the dynamics of exploited fish pupations. Fish. Invest. London. Series 2, 19: 553.

BEVERTON, R.J.H and HOLT, S.J. 1966. Manual of Methods for Fish Stock Assessment, Part 2. In: Tables of Yield Functions, Fisheries Technical Paper No. 38. Food and Agriculture Organization of the United Nations, Rome, Italy, pp. 7-29.

DAS, B.R. 1980. Population dynamics of Harpadon nehereus (Ham. Buch.) in the Karnafully river estuary, Chittagong. M. Sc. Thesis, Institute of Marine Sciences, University of Chittagong, Bangladesh. pp. 47-62.

GAYANILO, F.C. and PAULY, D. 1997. The FAO ICLARM Stock Assessment Tools (FiSAT): Reference Manual. Food and Agriculture Organization of the United Nations, Rome, Italy. pp. 15-42.

GAYANILO, F.C., SPARRE, P. and PAULY, D. 2005. FAO-ICLARM Stock Assessment Tools II(FiSAT II), User's Guide, Computerized Information Series (Fisheries) No. 8, (Revised Version), Food and Agriculture Organization of the United Nations, Rome, Italy.

GULLAND. J.A. 1971. The Fish Resources of the Oceans, Fishing News, London, 1971, p. 9-52.

ISLAM, S.S. 1995. Population dynamics of some fishes and shrimp of Karnafully river estuary based on length-frequency data. M. Sc. Thesis, Department of Zoology, University of Chittagong, Bangladesh. 37-76 pp.

JONES, R. and ZALINGE, N.P.V. 1981. Estimations of mortality rate and population size for shrimp in Kuwait Waters. Kuwait Bull of Marine Science 2: 273-288.

KHAN, M.Z. 1989. Population Dynamics of Bombay Duck, Harpodon nehereus (HAM.), Off Saurashtra Coast. Indian J. Fish. 36(2): 93 -101.

KURIAN, A, and KURUP, N. 1992. Stock Assessment of Bombay Duck H. nehereus (Hamilton) off Maharastra Coast. Indian J. Fish. 39(3\&4).

MOREAU, J. and CUENDE, F. X.1991. On improving the resolution of the recruitment patterns of fishes. Fish byte 9(1): 45-46. 
MUSTAFA, M.G., AZADI, M.A. and ISLAM, M.S.1994. ELEFAN based population dynamics of Bombay duck Harpadon nehereus Hamilton-Buchman from the Kumira estuary. Paper presented 9th National Zool. Conf. of the Zoological Society of Bangladesh. 26-28 Jan., (Souvenir abstract no. 42).

MUSTAFA, M.G, ZAFAR, M, MATIN, A.K.M. A. and AMIN, S.M. N. 1998. Population dynamics of Harpadon nehereus (Hamilton- Buchannan.) from the Kutubdia channel of Bangladesh. Bangladesh J. Fish. Res. 2(1): 83-90.

MUSTAFA, M.G. 2003.Trophic model of the coastal ecosystem in the waters of Bangladesh, Bay of Bengal. World Fish Center Conference Proceedings. 67: 263-280.

PAULY, D. and GASCHUTZ. 1979. A simple method for fitting oscillating length growth data, with a program for pocket calculators. International Council for the Exploration of the Sea, C.M. 1979/G: 24, pp. 26.

PAULY, D. 1980. On the interrelationship between natural mortality, growth parameters and mean environmental temperature in 175 fish stocks. Journal of the CIEM 39: 175-192.

PAULY, D. 1983. Some simple methods for the assessment of tropical fish stocks. FAO Fish Tech. Pap. 234: 52.

PAULY, D. 1984. Fish population dynamics in tropical waters: A manual for use with programmable calculators. ICLARM Stud. Rev. 8: 325.

PAULY, D. 1987. Review of the ELEFAN System for analysis of length-frequency data in fish and aquatic invertebrates. In: Pauly, D. and Morgan, G.R. eds., Length-Based Methods in Fisheries Research, Conference Proceedings, International Center for Living Aquatic Resource Management, Manila, Philippines, pp. 5-8.

PAULY, D. and MUNRO, J. 1984. Once more on the comparison of growth in fish and invertebrates. ICLARM Fish byte 2(1): 21.

RICKER, W.E. 1975. Computation and interpretation of biological statistics of fish populations. Bull. Fish. Res. Board Can. 191: 382.

RUSSELL, B.C., ANDERSON, G.R.V. and TALBOT, F.H. 1977. Seasonality and recruitment of coral reef fishes. Australian Journal of Marine and Freshwater Research 28: 52 1-528.

SILVESTRE, G.T. and GARCES, L.R. 2004. Population parameters and exploitation rate of demersal fishes in Brunei Darussalam. Fish Research, 69: 73-90.

WETHERAll. A., POLOVINA, J.J. and RALSTON, S. 1987. Estimating Growth and Mortality in Steady-State Fish Stocks from Length-Frequency Data. In: Pauly, D. and Morgan, G. R. (Eds.). Length-Based Methods in Fisheries Research, Conference Proceedings, International Center for Living Aquatic Resource Management, Manila, Philippines. pp. 1-22.

WILLIAMS, D. M.C. B., and SALE, P.F. 1981. Spatial and temporal patterns of recruitment of juvenile coral reef fishes to coral habitats within 'One-Tree Lagoon', Great Barrier Reef. Marine Biology. 65: 245-253. 